\title{
ETS Translocation Variant 3
}

National Cancer Institute

\section{Source}

National Cancer Institute. ETS Translocation Variant 3. NCI Thesaurus. Code C17806.

ETS translocation variant $3(512 \mathrm{aa}, \sim 57 \mathrm{kDa})$ is encoded by the human ETV3 gene. This protein is involved in the negative regulation of transcription. 